\title{
norden
}

\section{Yhteiset haasteet ja pohjoismainen hyöty}

Pohjoismaiden ministerineuvoston työelämäalan yhteistyöohjelma 2013-2016

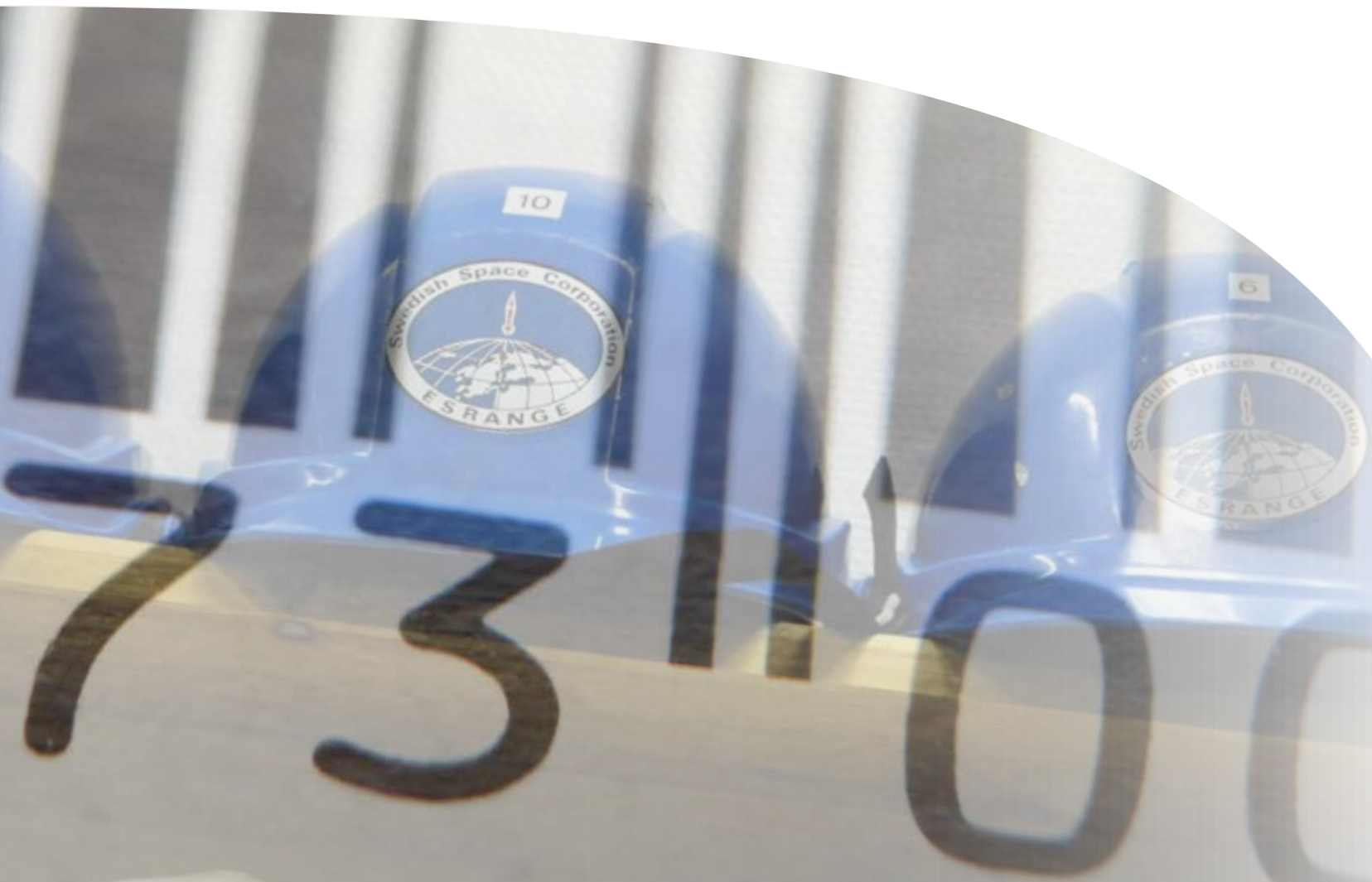




\section{Yhteiset haasteet ja pohjoismainen hyöty}

Esipuhe $\quad 5$

$\begin{array}{ll}\text { Tiivistelmä } & 7\end{array}$

Johdanto 9

Työelämäalan päähaasteet $\quad 10$

Painopistealueet ja tavoitteet ohjelmakaudella $\quad 12$

- Työllisyys- ja työmarkkina-ala 12

- Työympäristö- ja työoikeusala 14

- Monialaiset painopistealueet ja rajaesteiden torjuminen $\quad 17$

$\begin{array}{lr}\text { Yhteistyön puitteet } & 18\end{array}$ 


\section{Yhteiset haasteet ja pohjoismainen hyöty}

Pohjoismaiden ministerineuvoston työelämäalan

yhteistyöohjelma 2013-2016

ISBN 978-92-893-2484-7

http://dx.doi.org/10.6027/ANP2013-714

ANP 2013:714

(C) Pohjoismaiden ministerineuvosto 2013

Ulkoasu: Jette Koefoed

Valokuvat: Magnus Fröderberg s. 8, 12, 14;

ImageSelect s. 11, 13; Johannes Jansson s. 15;

Karin BeateNøsterud s. 16

Kannen valokuva: ImageSelect; Johannes Jansson/NMR

Painos: 100

Paino: Scanprint

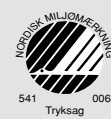

www.norden.org/fi/julkaisut

Printed in Denmark

\section{Pohjoismainen yhteistyö}

Pohjoismainen yhteistyö on yksi maailman laajimpia alueellisia yhteistyömuotoja. Yhteistyön piiriin kuuluvat Islanti, Norja, Ruotsi, Suomi ja Tanska sekä Ahvenanmaa, Färsaaret ja Grönlanti.

Pohjoismaista yhteistyötä tehdään politiikan, talouden ja kulttuurin aloilla tärkeänä osana eurooppalaista ja kansainvälistä yhteistyötä. Pohjoismaisen yhteisön tavoitteena on vahva Pohjola vahvassa Euroopassa.

Pohjoismainen yhteistyö pyrkii vahvistamaan pohjoismaisia ja alueellisia etuja ja arvoja globaalissa maailmassa. Maiden yhteiset arvot lujittavat osaltaan Pohjolan asemaa yhtenä maailman innovatiivisimmista ja kilpailukykyisimmistä alueista.

\section{Pohjoismaiden ministerineuvosto}

Ved Stranden 18

DK-1061 København K

Puhelin (+45) 33960200

www.norden.org 


\section{Esipuhe}

Työelämän ministerineuvosto (MR-A) määrittelee vuosia 2013-2016 koskevassa yhteistyöohjelmassaan strategiset painopisteet Pohjoismaiden hallitustenväliselle viralliselle työelämäalan yhteistyölle.

Ohjelmakauden aikana Pohjoismaiden työmarkkinat joutuvat kohtaamaan useita yhteisiä globalisaation ja väestörakenteen muutoksen aiheuttamia pitkän aikavälin haasteita. Lyhyellä aikavälillä saattaa ilmetä myös suhdanteiden aiheuttamia ongelmia ja äkillisiä kriisejä. Nämä haasteet kohdistuvat pitkällä aikavälillä pohjoismaisten hyvinvointiyhteiskuntien kilpailukykyyn, kestävyyteen ja yhteenkuuluvuuteen.

Työelämän ministerineuvoston yhteistyöohjelma määrittelee yhteistyön tärkeimmät tavoitteet, joilla parannetaan Pohjoismaiden mahdollisuuksia vastata työelämäalan haasteisiin. Näitä haasteita ovat muun muassa työmarkkinoiden tarvitseman työvoiman hankkiminen ja kouluttaminen sekä heikossa asemassa olevien ryhmien ja etenkin nuorten pitkäaikaistyöttömyyden torjuminen. Lisäksi painotetaan hyvää työympäristöä ja työntekijöiden voimavarojen kestävää hyödyntämistä, sosiaalisen polkumyynnin ja työsyrjinnän torjumista, työsuhdeturvan ja joustavuuden välis- tä tasapainoa sekä kansainväliseen sääntelyyn liittyvää pohjoismaista yhteistyötä. Tärkeänä monialaisena painopistealueena on myös rajaesteiden torjuminen ja purkaminen pohjoismaisilla työmarkkinoilla. Lisäksi ohjelmassa määritellään yhteistyön sopimusperusta sekä toimintapuitteet.

Yhteistyön perustana olevista sopimuksista haluaisin mainita erityisesti sopimuksen yhteispohjoismaisista työmarkkinoista. Tämän sopimuksen turvin Pohjoismaiden kansalaiset ovat voineet vuodesta 1954 lähtien työskennellä ja asua missä tahansa Pohjoismaassa. Yhteispohjoismaiset työmarkkinat - maailman yhdentyneimmät alueelliset työmarkkinat - viettävät siten tämän ohjelmakauden aikana 60-vuotisjuhlavuottaan. Pohjoismailla on syytä olla tästä ylpeitä!

Toivon, että niin työelämäalan kuin muidenkin alojen pohjoismainen yhteistyö luo myös tulevaisuudessa perustan innovatiivisille ja kaukonäköisille yhteispohjoismaisille ratkaisuille.

\section{Halldór Ásgrímsson}

\section{Pääsihteerì}

Pohjoismaiden ministerineuvosto 

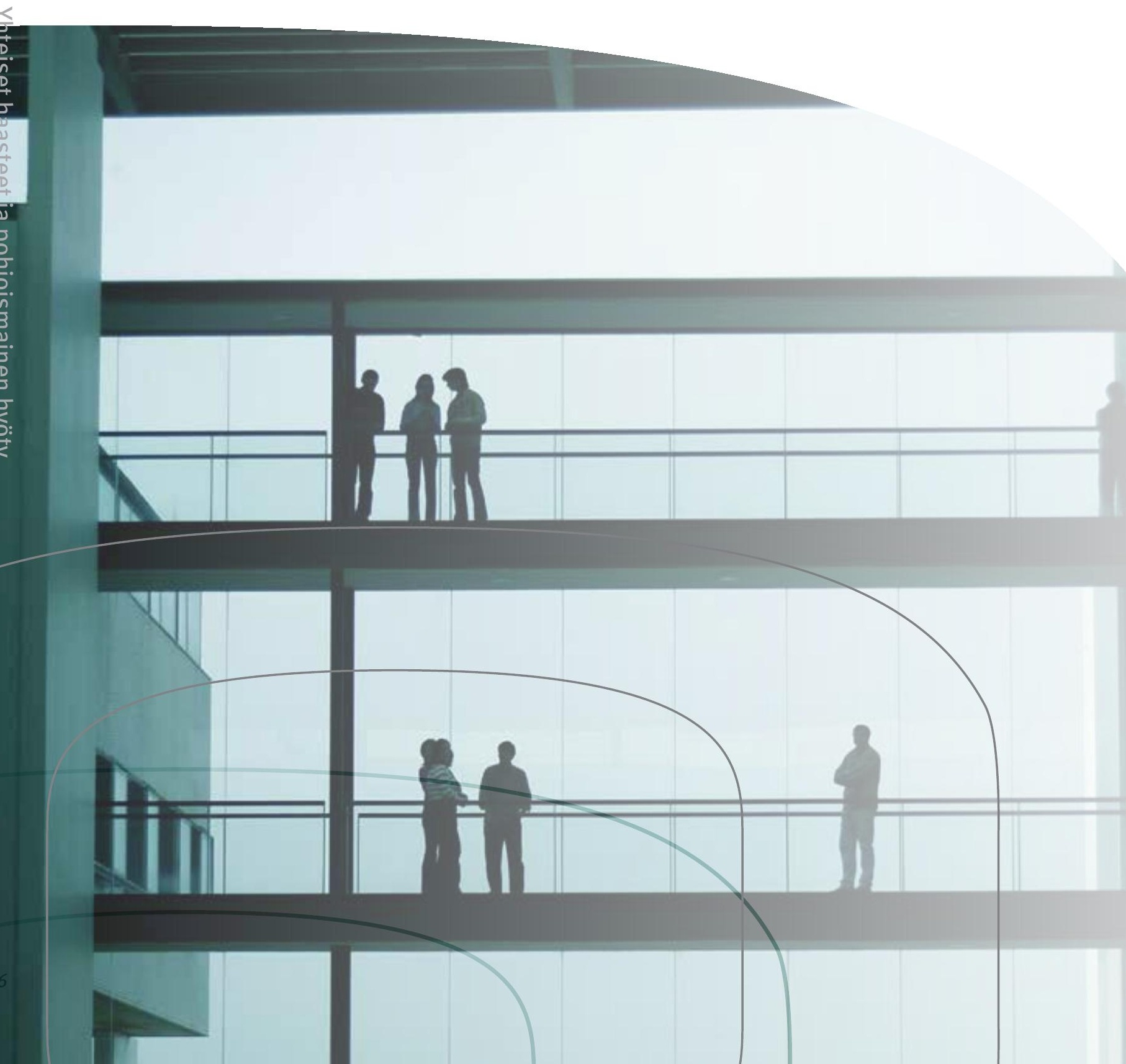


\section{Tiivistelmä}

Tämä yhteistyöohjelma määrittelee strategiset painopistealueet vuosiksi 2013-2016 Pohjoismaiden hallitustenväliselle viralliselle työelämäalan yhteistyölle. Ohjelmakaudella keskitytään globalisaatiosta ja väestörakenteen kehityksestä aiheutuviin pitkän aikavälin haasteisiin, mutta yhteistyössä priorisoidaan tarpeen mukaan myös kauden kuluessa syntyviä suhdannevaihteluista aiheutuvia haasteita.

Yhteistyön pääpaino on jatkossakin työelämän ministerineuvoston johdolla tapahtuvassa kokemusten- ja tiedonvaihdossa yhteisiin haasteisiin liittyvistä kansallisista toimista ja niiden tuloksista. Yhteistyö edistää samalla tärkeää työelämäalan viranomaisten verkottumista Pohjoismaissa. Pohjoismaiden välinen kokemusten- ja tiedonvaihto, verkottuminen ja keskinäinen koordinointi EU-aloitteissa ja neuvotteluissa sekä EU-direktiivien täytäntöönpanossa ovat myös keskeisellä sijalla yhteistyössä.

\section{Työllisyys- ja työmarkkina-alan} yhteistyön tärkeimpänä painopistealueena on työvoiman tarjonnan ja työllisyyden lisääminen sekä naisten ja miesten rakenteellisen työttömyyden vähentäminen.
Tavoitteena on edistää kestävää julkista taloutta ja pohjoismaisten hyvinvointiyhteiskuntien kestävää kehitystä sekä vahvistaa syrjäytyneiden ryhmien osallistumista yhteiskuntaan. Pyrkimyksenä on saada käyttöön sisäiset työvoimareservit, parantaa työvoiman tarjonnan ja kysynnän kohtaamista, edistää elinikäistä oppimista työmarkkinoiden tarpeiden mukaisesti, lisätä pohjoismaisten työmarkkinoiden vetovoimaa EU- ja Eta-alueen ulkopuolisen työvoiman kysyntään nähden, edistää alan viranomaisten välistä koordinointia sekä vähentää heikossa asemassa olevien ryhmien työttömyyttä ja pitkäaikaistyöttömyyttä. Nuorisotyöttömyyden torjuminen on yksi suurimmista haasteista ja tärkeimmistä painopistealueista.

Työympäristöalan yhteistyön tärkeimpänä painopistealueena on edistää sekä naisten että miesten turvallisuutta, terveyttä ja hyvinvointia työpaikalla. Tavoitteena on houkutteleva, motivoiva ja osallistava työympäristö, joka ehkäisee työperäisiä fyysisiä ja psyykkisiä terveysongelmia. Lisäksi työympäristöä kehitettäessä otetaan huomioon kansainväliset sopimukset ja EU-lainsäädäntö. Pyrkimyksenä on tukea hyvän työympäristön saa- 



\section{Johdanto}

Pohjoismaisella työelämäalan yhteistyöllä on pitkät perinteet. Yhteistyön piiriin kuuluu sekä Pohjoismaiden ministerineuvostossa että Pohjoismaiden neuvostossa tehtävä virallinen yhteistyö ja Pohjoismaiden välinen epävirallinen yhteistyö. Pohjoismaiden yhteinen arvopohja ja monet yhteiset piirteet luovat hyvät mahdollisuudet oppia toisten kokemuksista ja koordinoida näkemyksiä silloin, kun se on aiheellista ja tuo pohjoismaista hyötyä. Yhteistyötä tehdään siis aloilla, joilla maat yhdessä saavuttavat enemmän kuin kukin maa erikseen.

Tämän yhteistyöohjelman tarkoituksena on määritellä työelämän ministerineuvostossa tehtävän virallisen hallitustenvälisen pohjoismaisen yhteistyön strategiset painopistealueet vuosiksi 20132016. Yhteistyö kattaa työllisyysja työmarkkina-alan sekä työympäristö- ja työoikeusalan.

Ohjelman tavoitteena on määrätietoinen pohjoismainen yhteistyö sellaisten aloitteiden parissa, joista saadaan pohjoismaista hyötyä ja joiden avulla voidaan parantaa Pohjoismaiden mahdollisuuksia vastata ajankohtaisiin yhteisiin haasteisiin.

Yhteistyön periaatteena on vastaisuudessakin selvittää, analysoida ja pohtia yhteisiä haasteita koskevien kansallisten toimenpiteiden ja niiden tulosten yhtäläisyyksiä ja eroja. Lisäksi virallinen yhteistyö luo työelämäalan pohjoismaisten viranomaisten välille tärkeitä verkostoja, joista mailla on merkittävää hyötyä käytännön tilanteissa.

Yhteistyössä kiinnitetään erityistä huomiota tavoitteisiin, joilla pyritään vastaamaan globalisaatiosta ja väestörakenteen kehityksestä Pohjoismaiden työmarkkinoille aiheutuviin pitkän aikavälin haasteisiin. Yhteistyöhön sisältyy myös välttämätön joustovara, jolloin tarvittaessa voidaan keskittyä ohjelmakauden aikana mahdollisesti esille tuleviin suhdanteista johtuviin haasteisiin.

Yhteistyötä konkretisoidaan tarkemmin puheenjohtajamaiden vuotuisissa sektoriohjelmissa ja kunkin yhteistyöalan vuotuisissa toimintasuunnitelmissa. 


\section{Työelämäalan päähaasteet}

Työelämällä on tärkeä merkitys pohjoismaisten hyvinvointiyhteiskuntien, elinkeinoelämän ja yksilön kehitykselle. Työelämän päähaasteilla on siten huomattava vaikutus monella eri tasolla Pohjoismaissa. Kaikkien Pohjoismaiden hallitukset pohtivat jatkuvasti, kuinka näihin haasteisiin voidaan vastata työelämäpolitiikalla ja yhteistyöllä työmarkkinaosapuolten kanssa ja siten edistää kasvua ja työllisyyttä. Työelämäalalla tehtävän pohjoismaisen yhteistyön kautta hallitukset saavat hyödyllistä tietoa ja virikkeitä tähän työhön.

Pohjoismaiden työmarkkinoiden kehitykseen vaikuttavat yhä vahvemmin pitkän aikavälin kehityssuunnat, joista tärkeimpiä ovat globalisaatio ja väestönkehitys. Nämä kehityspiirteet tuovat sekä uusia mahdollisuuksia että uusia haasteita. Samalla työmarkkinoiden kehitys on suurelta osin riippuvainen suhdannevaihteluista, jotka vaativat nopeita reaktioita.

Globalisaation osalta pitkän aikavälin pääasiallisena haasteena on vahvistaa pohjoismaisten työmarkkinoiden sopeutumis- ja kilpailukykyä. Siten pystytään nopeasti tasaamaan äkillisiä rakennemuu- toksia ja korvaamaan työpaikkojen menetykset aloilla, jotka kärsivät kilpailun kiristymisestä maailmanmarkkinoilla, sekä tarjoamaan haluttua osaamista omaavaa työvoimaa uusille kasvualoille. Työvoima muuttuu vähitellen liikkuvammaksi globaalista näkökulmasta. Niinpä onkin entistä selkeämmin pyrittävä varmistamaan, että työsuhdeturva ja joustavuus ovat tasapainossa ja että työvoimalla on työmarkkinoiden tarvitsemaa osaamista.

Globalisaatio lisää myös kilpailua parhaista kyvyistä ja osaajista maailmanmarkkinoilla. Pääasiallisena haasteena on vahvistaa ja profiloida Pohjoismaissa asumisen ja työskentelyn etuja sekä tehdä pohjoismaisista työmarkkinoista entistä houkuttelevammat tarjoamalla muun muassa hyvät työehdot ja hyvän työympäristön, joka ehkäisee terveysongelmia, parantaa viihtyvyyttä ja motivaatiota sekä edistää työuran pidentämistä.

Väestörakenteen kehityksen osalta pitkän aikavälin päähaasteena on edelleenkin varmistaa riittävä työvoiman saatavuus sekä yksityisellä että julkisella sektorilla. Tämä on ratkaisevan tärkeää yksityisyritysten kasvumahdollisuuksille, julkisen sektorin mahdollisuuksille tyydyttää hyvinvointipalveluiden kasvava tarve ja pohjoismaisten hyvinvointiyhteiskuntien rahoitukselle tulevaisuudessa.

Haaste voi olla erityisen vaativa Pohjoismaille, joissa työmarkkinoille osallistumisen aste on entuudestaan korkea. Muita haasteita ovat suhteellisen korkeat sairauspoissaolojen määrät Pohjoismaissa ja eri syistä työmarkkinoiden ulkopuolella olevan ja julkisen tuen varassa elävän pohjoismaisen työikäisen väestön suuri osuus.

\section{Työelämäpolitiikan keskeisinä} haasteina on pitää työvoimatarjonta korkealla tasolla muun muassa työuria pidentämällä ja vahvistaa yhteiskunnan syrjäytyneiden ryhmien pääsyä työmarkkinoille. Tämä asettaa uusia, entistä suurempia vaatimuksia työympäristölle yrityksissä ja virastoissa, työn organisoinnille ja työolojen sopeuttamiselle yksittäisen työntekijän tarpeiden mukaan. Alan päähaasteena on myös varmistaa, että työntekijöiden tiedot ja osaaminen vastaavat työmarkkinoiden kysyntää ja että yhä enemmän työvoimaa ja palveluntarjoajia rekrytoidaan Pohjoismaiden ulkopuolelta - myös EU:n ja Etan ulkopuolisista maista. 
Globalisaatio ja väestörakenteen kehitys lisäävät tarvetta saada enemmän ulkomaista työvoimaa Pohjoismaihin, mutta samalla kasvava maahanmuutto asettaa haasteita pohjoismaiselle mallille. Tämä voi voimistaa joihinkin hyvinvointipalveluihin kohdistuvia paineita, tiukentaa matalapalkkakilpailua sekä lisätä työterveyttä ja -turvallisuutta koskevien sääntöjen kiertämistä. Työelämäpolitiikan keskeinen haaste onkin varmistaa, että työehtosopimuksia noudatetaan, ja torjua sosiaalista polkumyyntiä sekä puutteellisia työoloja. Tämä auttaa olennaisesti yhtäläisten ja terveiden kilpailuedellytysten luo- mista yrityksille ja palkansaajille pohjoismaisilla työmarkkinoilla.

Lisäksi haasteena on tukea Pohjoismaiden työmarkkinoiden kykyä sopeutua vähähiilisempään talouteen ja vastata pätevän työvoiman kysyntään muutoksen seurauksena syntyvillä uusilla sektoreilla ja aloilla.

\section{Suhdanteista johtuvan työttömyy-} den nousun osalta päähaasteena on useimmiten torjua tehokkaasti lyhyellä varoitusajalla nuorten ja muiden heikossa asemassa olevien ryhmien lisääntyvää työttömyyttä sekä kasvavaa pitkäaikais- työttömyyttä, jolla voi olla vakavia seurauksia yksittäiselle ihmiselle, julkiselle taloudelle ja pohjoismaiselle hyvinvointimallille. 


\section{Painopistealueet ja tavoitteet ohjelmakaudella}

Työelämäalan pohjoismaisen yhteistyön yleisenä tavoitteena on turvata toimivat pohjoismaiset työmarkkinat ja hyvä työelämä kilpailukykyisessä Pohjolassa.

Koko työelämäalan yhteistyössä kiinnitetään huomiota siihen, miten voidaan parhaiten edistää sukupuolten välistä tasa-arvoa työmarkkinoilla sekä torjua syrjintää ja työehtojen ja työympäristön perusteettomia eroja esimerkiksi sukupuolen, alentuneen työkyvyn, iän tai etnisen alkuperän takia. Erityisesti kiinnitetään huomiota työmarkkinoiden eriytymiseen.
Seuraavassa on esitetty pohjoismaisen hallitustenvälisen yhteistyön tärkeimmät ohjelmakauden tavoitteet työllisyys- ja työmarkkina-alalla sekä työympäristö- ja työoikeusalalla.

Joustava yhteistyö mahdollistaa keskittymisen myös suhdanteista johtuviin haasteisiin, erilaisiin kriisitilanteisiin ja mahdollisiin ohjelmakaudella tehtäviin tärkeisiin muutoksiin poliittisissa ja alakohtaisissa painopistealueissa.

Tavoitteita konkretisoidaan kunkin puheenjohtajamaan vuo- tuisissa sektoriohjelmissa sekä eri alojen jaostojen vuotuisissa toimintasuunnitelmissa ja teemavalinnoissa.

\section{Työllisyys- ja työmarkkina- ala}

Työllisyys- ja työmarkkina-alan keskeisenä painopistealueena on työvoiman tarjonnan ja työllisyyden lisääminen varsinkin nuorten osalta sekä rakenteellisen työttömyyden vähentäminen. Talouspolitiikan sekä koulutus- ja työmarkkinapolitiikan yhteistoiminnalla on tässä yhteydessä tärkeä 
merkitys. Yhteistyö on alan EU- ja Eta-yhteistyön mukaista ja täydentää sitä.

Työllisyys- ja työmarkkina-alan tärkeimmät tavoitteet ovat:

\section{Hyödynnetään sisäistä työvoimare-} serviä mahdollisimman tehokkaasti

Tavoitteena on osallistaa nuoret, opiskelijat mukaan lukien, aikaisemmin ja paremmin työelämään sekä pitää ikääntyneet kauemmin töissä. Lisäksi pyrkimyksenä on vähentää sairauspoissaoloja ja saada maahanmuuttajataustaiset henki-

löt, osatyökykyiset ja muut heikosti työmarkkinoille sijoittuneet ryhmät nykyistä tiiviimmin mukaan työelämään. Tärkeän työvoimaresurssin tarjoavat myös henkilöt, jotka ovat jo osapäivätyössä ja haluavat lisätä työpanostaan.
Parannetaan työvoiman kysynnän ja tarjonnan kohtaamista

Keskitytään siihen, miten liikkuvuutta työmarkkinoilla voidaan lisätä pullonkaulojen vähentämiseksi ja sen välttämiseksi, että tietyillä aloilla esiintyy samanaikaisesti sekä työttömyyttä että työvoimapulaa. Huomiota kiinnitetään muun muassa kannusterakenteisiin ja yksittäiseen työntekijään kohdistuviin vaatimuksiin sekä työnvälityksessä käytettäviin menetelmiin ja välineisiin. Ammattipätevyyden vastavuoroinen tunnustaminen on edelleenkin ajankohtainen aihe.

\section{Edistetään työmarkkinoiden tarpeisiin mukautettua elinikäistä oppimista}

Keskitytään siihen, miten voidaan parhaiten kehittää työvoiman osaamista ja taitoja tiiviissä yhteydessä kysyntään. Tavoitteena on varmistaa, että työvoiman taidot vastaavat jatkuvasti yksityisten ja julkisten työmarkkinoiden tarpeita. Tämä koskee yleisesti nuorten koulutuksia ja aikuisten osaamisen kehittämistä, mutta tavoite on tärkeä myös ikääntyneiden saamiseksi töihin ja pitämiseksi työmarkkinoilla sekä muita heikommassa asemassa olevien ryhmien osallistamiseksi työmarkkinoille.

\section{Torjutaan heikossa asemassa olevien ryhmien työttömyyttä ja pitkäaikaistyöttömyyttä}

Keskitytään korkean nuorisotyöttömyyden torjumiseen tehokkailla työmarkkina- ja koulutuspoliittisilla toimilla tavoitteena osaamisen vahvistaminen ja työmarkkinoille pääsyn edistäminen. Erityistä huo- 
miota kiinnitetään puutteellisen koulutuksen omaaviin työttömiin nuoriin. Lisäksi huomion kohteena ovat muut ryhmät, joiden on vaikea päästä työmarkkinoille, esimerkiksi maahanmuuttajat, huonosti koulutetut, osatyökykyiset ja pitkäaikaistyöttömät.

\section{Parannetaan vetovoimaa EU- ja Eta-alueen ulkopuolisen työvoiman kysyntään nähden}

Kiinnitetään huomiota siihen, kuinka pohjoismaisten työmarkkinoiden vetovoimaa voidaan vahvistaa tai kehittää EU- ja Eta-alueen ulkopuolelta tulevan ulkomaisen työvoiman kysyntään nähden. Työperäisen maahanmuuton, talouskasvun ja pohjoismaisten hyvinvointijärjestelmien pitkän aikavälin kestävyyden välinen yhteys on tässä keskeisenä haasteena.

\section{Edistetään alan viranomaisten välistä koordinointia}

Keskitytään alan viranomaisten ja hallinnonalojen välisen koordinoinnin vahvistamiseen kansallisesti ja maiden välillä. Tavoitteena on parantaa työttömien, sairaiden ja työttömyyden lisäksi muista ongelmista kärsivien henkilöiden mahdollisuuksia päästä nopeasti ja tehokkaasti aktiiviseen työelämään.

\section{Työympäristö- ja työoikeusala}

Työympäristöalan yhteistyön päätavoitteena on edistää työturvallisuutta, työterveyttä ja työhyvinvointia. Tavoitteena on houkutteleva, motivoiva ja osallistava työympäristö, joka ehkäisee työperäisiä terveysongelmia. Lisäksi työympäristöä kehitettäessä otetaan huomioon kansainväliset sopimukset ja EU-lainsäädäntö.

Työoikeuden alan yhteistyön pääpainopisteenä on seurata pohjoismaisen mallin toimintaedellytyksiä, haasteita ja sopeuttamista sekä kehittää sitä työ- ja elinkeinoelämän muuttuessa yhä globaalimmaksi.

Kummallakin alalla keskitytään erityisesti parantamaan Pohjoismaiden välistä tiedon ja kokemusten vaihtoa, verkottumista ja keskinäistä koordinointia työympäristö- ja työoikeusalan sääntelyn kannalta tärkeiden EUaloitteiden ja neuvottelujen sekä erityisesti EU-direktiivien täytäntöönpanon yhteydessä. 


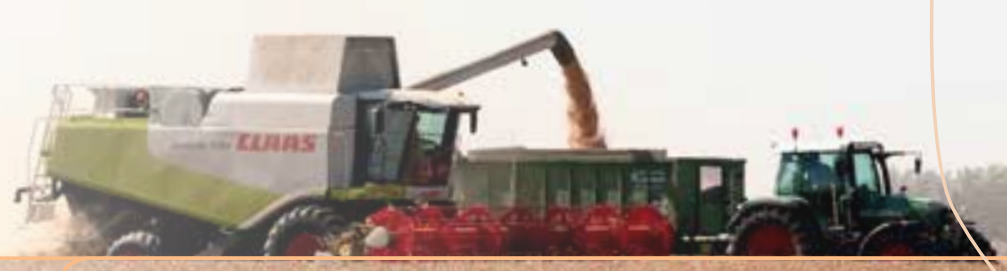

Työympäristö- ja työoikeusalan yhteistyön tärkeimmät tavoitteet ovat:

\section{Vahvistetaan hyvää fyysistä ja psyykkistä työympäristöä työpaikoilla}

Keskitytään fyysisten, psyykkisten, organisatoristen ja sosiaalisten olojen kehittämiseen ja parantamiseen työpaikoilla. Etusijalla on järjestelmällinen ja ennaltaehkäisevä toiminta työtapaturmien ja työperäisten sairauksien vähentämiseksi. Hyvä työympäristö auttaa lisäksi pidentämään työuraa ja tukee osaltaan aktiivista ikääntymistä. Huomiota kiinnitetään muun muassa eniten kuormitettuihin ryhmiin, sektoreihin tai aloihin Pohjoismaiden työelämässä sekä tehokkaisiin menetelmiin tilanteen parantamiseksi. Muita tärkeitä aiheita ovat tavoitettavuuden lisääntymisestä ja palautumisen puutteesta aiheutuvat stressiperäiset oireet ja niihin liittyvät haasteet.

\section{Kehitetään työympäristö- strategioita ja -valvontaa}

Keskitytään työympäristöstrategioiden ja -valvonnan kehittämiseen siten, että otetaan huomioon EU:n työympäristöstrategia sekä muu alan kansainvälinen yhteistyö. Siinä yhteydessä vahvistetaan yhteistyötä Pohjoismaiden ja työmarkkinaosapuolten välillä ja seurataan tarkasti työympäristön kehitystä Pohjoismaissa sekä tunnistetaan tärkeät alat, joilla pohjoismaisesta yhteistyöstä voidaan odottaa olevan erityistä hyötyä.

Pyritään ehkäisemään puutteellisia työoloja, sosiaalista polkumyyntiä ja syrjintää työmarkkinoilla

Keskitytään siihen, kuinka Pohjolaa voidaan kehittää houkuttelevana työmarkkina-alueena, jolle on tyypillistä korkea osaamistaso sekä työehtojen ja työympäristön korkea taso. Tämä auttaa vetämään puoleensa tarvit- 
tavaa työvoimaa Pohjoismaiden ulkopuolelta. Samalla keskitytään ehkäisemään sitä, että kasvava työperäinen maahanmuutto ja matalapalkkakilpailu lisäävät puutteellisia työoloja, sosiaalista polkumyyntiä ja syrjintää pohjoismaisilla työmarkkinoilla. Tähän liittyen vaihdetaan kokemuksia hyvistä vaikutuskeinoista ja toimista sekä tarkastellaan mahdollisuuksia vahvistaa yhteistyötä alan pohjoismaisten viranomaisten välillä

\section{Tehdään näkyväksi hyvän johta- misen ja työntekijöiden aktiivisen osallistumisen merkitystä}

Kiinnitetään huomiota hyvän johtamisen ja työntekijöiden aktiivisen osallistumisen merkitykseen. Tavoitteena on korkeatasoinen työterveys ja työturvallisuus sekä hyvä työn tuottavuus niin yksityisellä kuin julkisellakin sektorilla.

\section{Vahvistetaan yksittäisten työntekijöiden voimavarojen kestävää käyttöä}

Keskitytään yksittäisten työntekijöiden voimavarojen kestävän käytön edistämiseen siten, että työ ja yksityiselämä voidaan yhdistää tyydyttävällä tavalla eri elämänvaiheissa. Näin ehkäistään stressiä, sairauspoissaoloja, loppuunkulumista, työelämästä syrjäytymistä ja varhaista työelämästä vetäytymistä. Tässä yhteydessä kiinnitetään huomiota työn joustavuuteen muun muassa työaikojen ja etätyön osalta.

\section{Säilytetään hyvä palkansaajan suojan ja jouston tasapaino}

Kiinnitetään huomiota malleihin, joiden avulla voidaan säilyttää hyvä työsuhdeturvan ja joustavuuden välinen tasapaino ja siten vahvistaa pohjoismaisten työ-

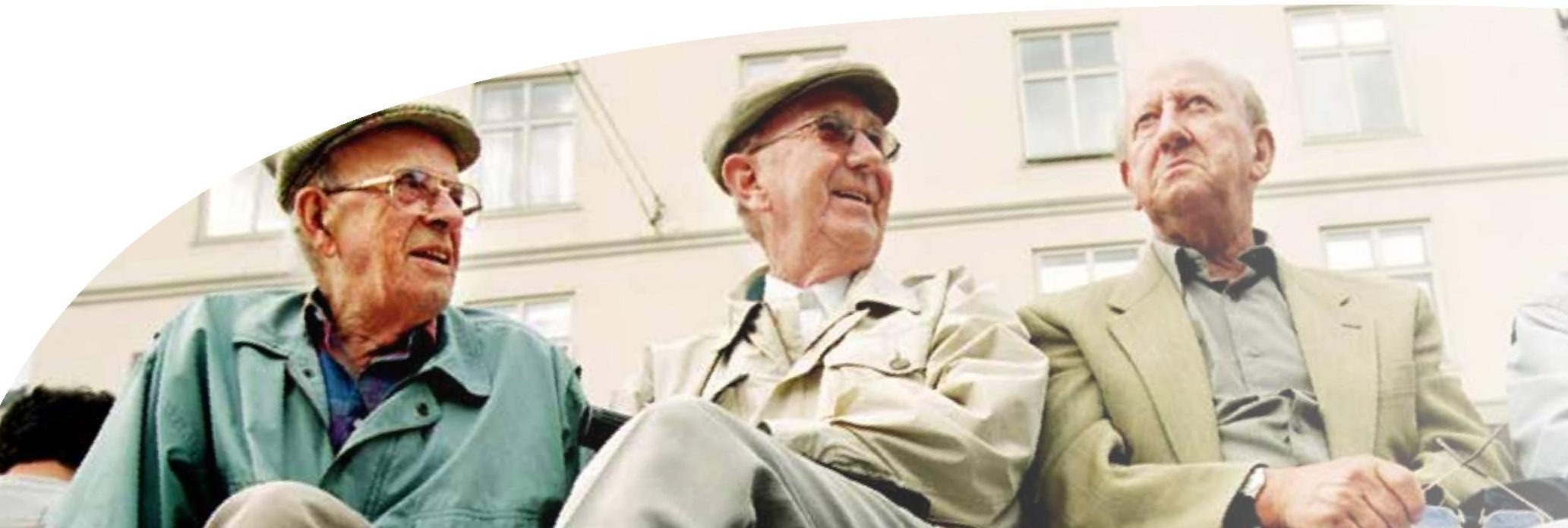


markkinoiden sopeutumiskykyä entisestään. Pyrkimyksenä on myös seurata, kuinka muutosprosesseja, uusia työmuotoja ja uusia työvoiman käyttötapoja voidaan organisoida ja toteuttaa ilman, että niillä on kielteinen vaikutus yksilöön, yrityksiin ja yhteiskunnan talouteen.

\section{Vahvistetaan pohjoismaista yh- teistyötä kansainväliseen säänte- lyyn liittyvissä kysymyksissä}

Keskeisenä aiheena on se, miten kansainvälisiä yhteyksiä koskevan työnjaon, kokemustenvaihdon ja yhteistyön avulla voidaan vaalia ja kehittää pohjoismaista mallia. Tämä koskee ennen kaikkea EU:ta, ILOa, Euroopan neuvostoa, OECD:tä, YK:ta ja kansainvälisiä standardointijärjestöjä.

\section{Monialaiset painopistealu- eet ja rajaesteiden torjumi- nen}

Monialaisena painopistealueena on edelleenkin rajaesteiden ehkäiseminen ja purkaminen pohjoismaisilla työmarkkinoilla. Kukin maa kantaa vastuuta rajaestetyöstä ja lisäksi työelämän ministerineuvosto seuraa aihetta tarkasti. Työelämäsektori on tehnyt yhteistyössä sosiaali- ja terveyspolitiikan ministerineuvoston kanssa perusteellisen selvityksen sosiaali- ja työmarkkina-alan rajaesteistä Pohjoismaissa. Todelliset rajaesteet aiheuttavat tarpeetonta kitkaa yhteispohjoismaisilla työmarkkinoilla. Esteiden vähentäminen parantaa Pohjoismaiden kansalaisten mahdollisuuksia muuttaa ja saada työtä toisessa
Pohjoismaassa sekä pätevän työvoiman saantia Pohjoismaiden sisältä. Yhteistyö EURES-työnvälitysverkoston kanssa on tärkeää tässä yhteydessä.

Työelämän ministerineuvosto tekee yleisesti yhteistyötä muiden Pohjoismaiden ministerineuvoston alaisten sektorien ja laitosten sekä muiden kansainvälisten järjestöjen kanssa silloin, kun se tuo pohjoismaista hyötyä. Yhteistyötä Pohjoismaiden lähialueiden kuten Baltian maiden ja Puolan kanssa jatketaan tarpeellisiksi katsotuilla aloilla. 


\section{Yhteistyön puitteet}

Työmarkkina-alan pohjoismaisen yhteistyön peruskivenä on ollut vuodesta 1954 saakka sopimus Pohjoismaiden yhteisistä työmarkkinoista. Sitä uudistettiin viimeksi vuonna 1982, minkä jälkeen se tuli voimaan vuonna 1983. Sopimuksessa Pohjoismaiden hallitukset korostavat muun muassa sitä, että kansalaisten perusoikeuksiin kuuluu oikeus saada vapaasti työskennellä ja asua toisessa Pohjoismaassa. Lisäksi sopimuksessa tähdennetään, että hallitusten tavoitteena on ylläpitää maissaan täystyöllisyyttä sekä toimia yhteistyössä tämän tavoitteen saavuttamiseksi. Työvoiman vapaa liikkuvuus toimii Pohjoismaissa EU- ja Etasopimusten sitoumuksista huolimatta. Yhteisten eurooppalaisten työmarkkinoiden kehitys vaikuttaa kuitenkin yhä enemmän pohjoismaiseen yhteistyöhön, koska vapaata liikkuvuutta säätelevät pääasiallisesti EU-oikeus ja Eta-sopimus.

Työympäristöalan yhteistyö perustuu pohjoismaiseen työympäristösopimukseen, joka solmittiin vuonna 1989 . Sopimuksessa määritellään pohjoismaisen työympäristöalan yhteistyön pääperiaatteet. Siinä linjataan yhteistyön pääasiallinen sisältö ja tavoite, joka on yhä paremman, terveellisemmän ja turvallisemman työympäristön luominen.

Työelämän ministerineuvostolla (MR-A) on päävastuu pohjoismaisesta työelämäalan yhteistyöstä. Se toimii tärkeänä keskustelu- ja kokemustenvaihtofoorumina, jolla Pohjoismaiden työllisyys-, työ- ja työympäristöministerit voivat pohtia parhaita tapoja vastata yhteisiin työelämäalan haasteisiin.

Yhteistyötä koordinoi työelämän virkamieskomitea (ÄK-A), joka laatii suuntaviivat työelämän ministerineuvoston budjetille ja jakaa budjettivarat. Organisaatiorakenteen on oltava joustava, jotta pohjoismaisessa yhteistyössä voidaan tehokkaasti toteuttaa ja seurata ajankohtaisia asioita. Työelämän virkamieskomitea on asettanut kolme pysyvää jaostoa: työmarkkinajaoston, työympäristöjaoston ja työoikeusjaoston. Lisäksi virkamieskomitea asettaa ad hoc -työryhmiä tarpeen mukaan.

Jaostoilla ja ad hoc -ryhmillä on tärkeä merkitys maiden välisessä kokemustenvaihdossa omilla vastuualueillaan. Pysyvät jaostot hallinnoivat myös hankemäärärahoja, joilla pääasiallisesti pyritään parantamaan kokemustenvaihdon perusteita. Tämä toteutetaan selvittämällä ja analysoimalla yhtäläisyyksiä ja eroja Pohjoismaiden toimissa ja niiden vaikuttavuudessa. Jaostot antavat myös oman panoksensa työelämän virkamieskomitean ja ministerineuvoston työhön tunnistamalla ja esittämällä käsiteltäväksi ajankohtaisia ja kiinnostavia poliittisia ja alaa koskevia aiheita.

Ohjelmakauden yhtenä tavoitteena on, että yhteistyössä kiinnitetään enenevästi huomiota kokemusten vaihtoon ja yhteisiin haasteisiin.

Työelämäalan yhteistyöhön kuuluu myös Helsingissä sijaitseva Pohjoismainen työsuojelukoulutusinstituutti (NIVA), joka järjestää työympäristöalan kursseja ja seminaareja englanniksi kaikkialla Pohjoismaissa (www.niva. org). Lisäksi ministerineuvosto toimii osarahoittajana Nordjobbohjelmassa, joka antaa nuorille pohjoismaalaisille mahdollisuuden kesätyöhön toisessa Pohjoismaassa (www.nordjobb. net). Ministerineuvosto rahoittaa myös työelämäalan pohjoismaista tiedotusohjelmaa, jonka kielet ovat englanti, norja, ruotsi ja tanska (www.arbeidslivinorden.org). 
Seuraavassa on esitetty vuoden 2012 tilannetta kuvaava organisaatiokaavio:

\section{Työelämän ministerineuvosto (MR-A)}

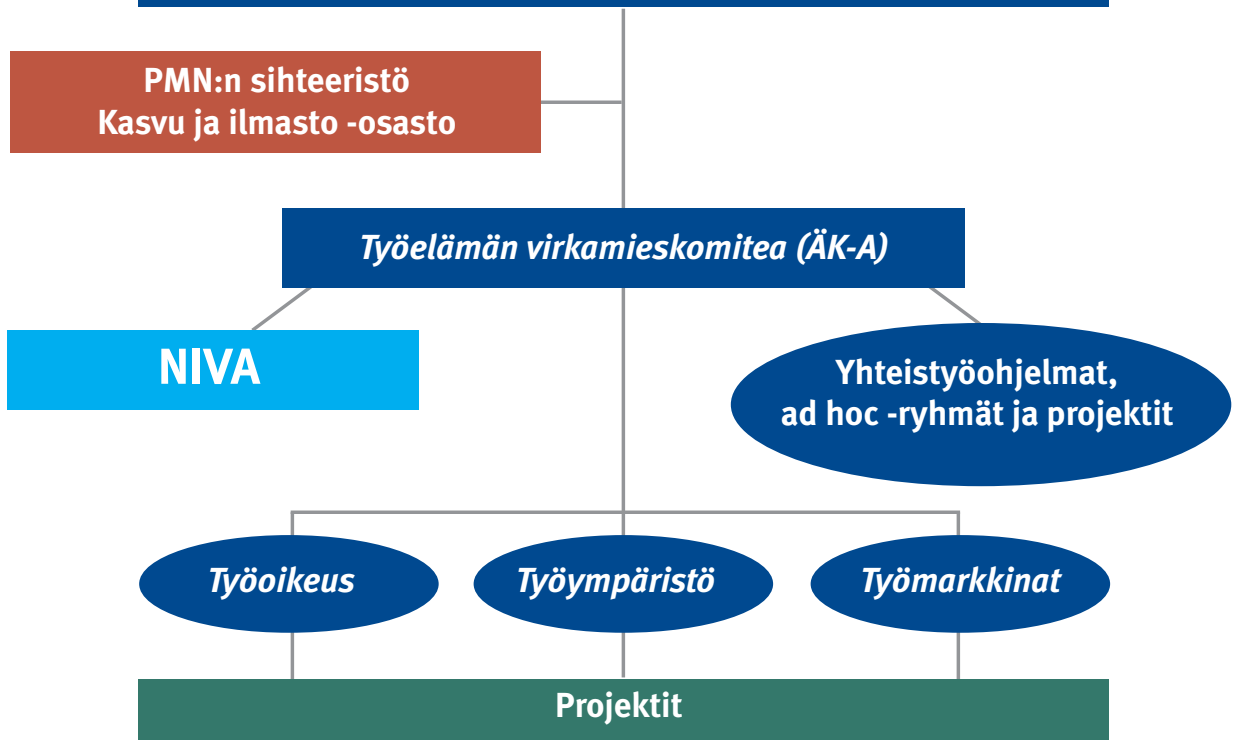

Jaostot, NIVA, Nordjobb ja tiedotusohjelma laativat vuosittain toimintasuunnitelman tulevalle vuodelle sekä toimintakertomuksen kuluneen vuoden tuloksista ja varojen käytöstä. Raportoinnin pohjalta työelämäalan virkamieskomitea päättää ministerineuvoston budjetin jaosta.
Työmarkkinaosapuolet ovat luonnollisesti tärkeässä asemassa työelämäpolitiikkaa ja pohjoismaisia hyvinvointiyhteiskuntia kehitettäessä ja samalla tärkeitä Pohjoismaiden ministerineuvoston yhteistyökumppaneita. Työelämän ministerineuvoston ja työmarkkinaosapuolten välinen yhteydenpi- to tarkoittaa joustavaa vuoropuhelua, jota käydään esimerkiksi teemakokouksissa, konferensseissa ja yhteisissä neuvonpidoissa.

Yhteistyöohjelman toteutumista on arvioitava ennen ohjelmakauden loppua seuraavan yhteistyöohjelman laatimisen helpottamiseksi. 


\section{nordon}

\section{Pohjoismaiden ministerineuvosto}

Ved Stranden 18

DK-1061 København K

www.norden.org

\section{Yhteiset haasteet ja pohjoismainen hyöty}

Työelämän ministerineuvosto määrittelee tässä nelivuotisessa yhteistyöohjelmassaan strategiset painopistealueet Pohjoismaiden hallitustenväliselle viralliselle työelämäalan yhteistyölle vuosiksi 2013-2016. Ohjelmakaudella keskitytään erityisesti globalisaatiosta ja väestörakenteen kehityksestä aiheutuviin pitkän aikavälin haasteisiin Pohjoismaiden työmarkkinoilla, mutta yhteistyössä priorisoidaan tarpeen mukaan myös kauden aikana syntyviä suhdannevaihteluista johtuvia haasteita.

Ohjelmassa otetaan esille joukko työllisyys- ja työmarkkina-alan sekä työympäristö- ja työoikeusalan yleisiä tavoitteita, jotka kaikki tähtäävät näihin haasteisiin vastaamiseen. Lisäksi ohjelmassa määritellään yhteistyön perusta ja yleiset puitteet. 